University of Minnesota Morris Digital Well

University of Minnesota Morris Digital Well

\title{
They Said, She Said: Making the Case for Rape in Fuenteovejuna
}

Stacey L. Parker Aronson

University of Minnesota - Morris

Follow this and additional works at: https://digitalcommons.morris.umn.edu/span_facpubs

Part of the Dramatic Literature, Criticism and Theory Commons, and the Spanish Literature Commons

\section{Recommended Citation}

Aronson, S. L. P. "They Said, She Said: Making the Case for Rape in Fuenteovejuna." Bulletin of the Comediantes, vol. 67 no. 2, 2015, pp. 33-47.

This Article is brought to you for free and open access by the Faculty and Staff Scholarship at University of Minnesota Morris Digital Well. It has been accepted for inclusion in Spanish Publications by an authorized administrator of University of Minnesota Morris Digital Well. For more information, please contact skulann@morris.umn.edu. 


\title{
They Said, She Said: Making the Case for Rape in Fuenteovejuna
}

\author{
Stacey L. Parker Aronson \\ University of Minnesota, Morris
}

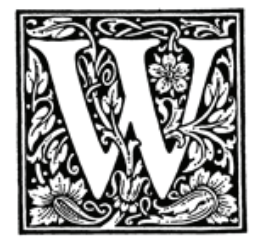

hile the rape of Laurencia in Lope de Vega's iconic early modern drama Fuenteovejuna serves as the catalyst that provokes the villagers to avenge the wrongs done to them by the Comendador Fernán Gómez, another female characterJacinta-suffers an equally if not more egregious assault. When she vigorously resists the Comendador's attempts to seduce her, he turns her over to his soldiers to be gang-raped like one of the spoils of war, telling her, "Ya no mía, del bagaje / del exército has de ser" (2.1270). I. A. A. Thompson's study War and Government in Habsburg Spain 1560-1620 demonstrates the danger soldiers posed to the general public:

The annual movement of forty or more companies [of soldiers] across Castile left in its wake a trail of destruction and rapine. An endless series of robberies, murders, rapes, malicious and wanton violence, jailbreaks, even pitched battles between soldiers and civilians repeated year after year stretched along all the most traversed routes of the kingdom. The coming of a company of soldiers was awaited with the same trepidation as a burricane. Those who could fled its path; those who could not were forced to abandon their trades to stay at home to protect their wives, their daughters, and their property. (113; my emphasis)

Strangely enough, Jacinta's gang-rape does not provoke the village to action nor garner as much critical attention as it warrants. Laurencia's abduction and rape occupies a privileged position in the drama even though numerous scholars argue against her having been raped at all. While it is obvious from Laurencia's physical description that she put up the proverbial fight of her life to fend off the Comendador's sexual advances, the only evidence these critics provide 
to corroborate their assertions that Laurencia was not raped is Frondoso's reference to what he considers her continuing virtue. Despite their allegations, textual and cultural evidence suggests that Laurencia was indeed raped. First, a consideration of her physical appearance is in order. Second, an overlooked comment by Jacinta evidences Laurencia's rape. Third, the quality attributed to Laurencia, namely her virtue, should be understood within its sociohistorical context during the early modern period, its understanding superseding an exclusively sexual meaning. Finally, this drama can be considered in light of its adherence to and subversion of what are termed "rape scripts."

Marcia L. Welles, the author of Persephone's Girdle: Narratives of Rape in Seventeenth-Century Spanish Literature, asserts that Laurencia is not raped by the Comendador: "Her virginity intact owing to her valiant efforts of defense (her virtue remains "unsullied"), the marriage with Frondoso ensures an ending appropriate to the paradigm of comedy and the mythos of romance" (89). Welles arrives at this conclusion when she acknowledges Frondoso's observation in the presence of the Catholic Monarchs, Fernando and Isabel, that Laurencia "en virtud florece" (3.2411). Welles interprets the comment to mean that Laurencia was not raped by the Comendador and that she defended her virginity against his sexual aggression.

Joaquín Casalduero equates Laurencia's honor-her virtue - with virginity, and insinuates that her physical condition evidences her resistance. Casalduero implies that if she put up a fight, the Comendador would not have been able to overcome her, a somewhat illogical assumption based, it seems, on the antiquated and misogynistic idea that, if a woman has been raped, she is to blame because she did not fight back with sufficient vigor. According to Casalduero,

Laurencia llega desmelenada. El desorden de su peinado es signo de ira, pero lo es porque al mismo tiempo es testimonio de la lucha sostenida para defender su bonor: "¿Qué dagas no vi en mi pecho? / ¡Qué desatinos enormes, / qué palabras, qué amenazas, / y qué delitos atroces, / por render mi castidad / a sus apetitos torpes! / Mis cabellos ¿no lo dicen?” ... Enormes y atroces palabras, amenazas, desatinos, delitos, que han ido a estrellarse inútilmente contra la fortaleza de la castidad de Laurencia, la cual no ba corrido ni por un momento el peligro de sucumbir. (Casalduero 46; my emphasis)

Victor Dixon concurs, observing, "Lope quiere tal vez que caigamos en la trampa de suponer que el Comendador ha podido 'render [su] castidad / a sus apetitos torpes'; pero nada nos autoriza a afirmarlo" (162). Dixon continues, "el 
efecto de su arenga fue incitar al pueblo no a vengar su honra sino a ayudarla a defenderla" (163; my emphasis).

In defense of these critics, whose perspective is novel albeit somewhat disturbing, neither Laurencia nor any of the other characters explicitly states that she has been raped. In addition, she does not behave in the prescriptive way raped women tended to behave in medieval and early modern literature: she does not retire quietly to a convent or commit suicide nor does her family repudiate her. In reality, not all raped women would have suffered banishment or abandonment, or would have been repudiated by their families. While some would have abandoned them, blaming the victims for their rapes, as was common, other families would have embraced them and comforted them. In his study Sex Crimes, Honour, and the Law in Early Modern Spain, historian Renato Barahona provides a plethora of anecdotal examples of families who supported their raped daughters in their efforts to secure justice and compensation for their victimization (119-56). For a literary example, Cervantes's novella "La fuerza de la sangre" represents parents who lovingly embrace their daughter after she is abducted and raped: "Cuando la vieron corrieron a ella con los brazos abiertos, y con lágrimas en los ojos la recibieron" (Cervantes 156). When Leocadia gives birth to a son as a result of the rape, her parents take great pains to protect her from public scrutiny. She gives birth in secret, with her mother in attendance, and her parents take the baby to another village to be nursed and raised for four years after which he is brought back home and raised as their nephew:

Con el mismo recato y secreto que había nacido le llevaron a una aldea, donde se crió cuatro años, al cabo de los cuales, con nombre de sobrino, le trajo su abuelo a su casa, donde se criaba, si no muy rica, al menos muy virtuosamente. (157)

In Fuenteovejuna, the severity of the sexual crimes committed by the Comendador escalates from seduction to violent sexual assault, and his victims range from the sexually promiscuous to the chaste. With the aid of his acolytes Flores and Ortuño, the Comendador is able to seduce at least seven women, four of whom are married or engaged. He mentions the seven women specifically, including the married Sebastiana, Pedro Redondo's wife, Martín del Pozo's fiancée (1.799-804), and later Pascuala, Olalla, Inés, and Antón's wife (2.1059-78). Their vulnerability seems connected to perceptions of their sexual promiscuity and poor reputations. He observes, "A las fáciles mujeres / quiero bien y pago mal" (2.1080-81). Even Laurencia blames a number of these women for their own potential victimization: "Éssas, señor, ya tenían, / de haber andado con otros, / el camino de agradaros, / porque también muchos moços / merecieron sus favores" (1.805-09). Abigail Dyer's article titled "Seduction by 
Promise of Marriage" suggests that the concepts of honor and reputation could be mutually exclusive in early modern Spanish culture.

Spanish law centered on two separate but intertwined legal concepts: honor and reputation. In secular and ecclesiastical courts, honor was commonly understood as being dependent upon extrinsic factors (for example, injury caused by another person). Reputation was understood as intrinsic, a quality inberent in an individual's character. Dishonor, ... was brought about through circumstances external to the dishonored party, such as an insult or a bodily attack. Ill repute, on the other hand, derived from the circumstances of $a$ person's birth or from law. (447-48; my emphasis)

While all of these women may be said to have been dishonored, their alleged promiscuity and resulting poor reputations lessen the seriousness of the offenses committed against them.

The Comendador has enjoyed unlimited, unfettered sexual access to almost all of the village women: "¡Cuántas moças en la villa / del Comendador fiadas, / andan ya descalabradas!" (1.193-95). Pascuala comments on the likelihood that Laurencia, too, will fall victim, noting that "Tendré yo por maravilla / que te escapes de su mano" (1.196-97) and more directly that "Y yo sospecho / que te han de engañar, Laurencia" (1.211-12). Laurencia is confident in her ability to resist seduction, confident that the persuasive words echoed by the Comendador's men will lack the power to turn her heart- "mas no serán poderosas / para contrastar mi pecho" (1.207-08)—and make her succumb to his sexual advances. However, this confidence does not guarantee her immunity to violent physical coercion.

Given that rape in early modern drama tended to occur off stage, the audience does not witness Laurencia's rape. After having been violently abducted, Laurencia reappears amidst the village men with her hair "desmelenada." In fact, she is so physically transformed that her own father does not immediately recognize her.

LAURENCIA. ... ¿Conocéisme?

ESTEBAN. ¡Santo cielo! ¿No es mi hija?

JUAN [ROXO]. ¿No conoces a Laurencia?

LAURENCIA. Vengo tal, que mi diferencia os pone en contingencia quién soy. (3.1716-20; my emphasis)

Those versed in medieval imagery will be able to interpret Laurencia's "desmelenada" hair as an indication that she has been raped. According to Diane 
Wolfthal's Images of Rape: The "Heroic" Tradition and Its Alternatives, loose and uncovered hair was a sign of sexual humiliation or rape (43). That physical marker, along with torn clothing, became emblematic of how a rape victim should look from as early as the eighth century. ${ }^{1}$ Wolfthal provides a veritable wealth of visual images to corroborate this idea: "In medieval art disheveled hair was a sign of rape and a man touching a woman's hair implied the threat of sexual violation" (70). Heath Dillard concurs with this assessment regarding the symbolic importance of a woman's hair in Daughters of the Reconquest:

to be cast to the ground was damaging to a woman's dignity but often most demeaning when engineered by a man, either when he feigned to rape her or uncovered her bair and caused it to fall from its fastening in ber coif. When a man removed a woman's coif or let down her hair, be assaulted her modesty and exposed her as defenseless and pregnable. (175; my emphasis)

Just because Laurencia does not explicitly state that she was raped does not signify that she was not, and an early modern audience would have been able to "read" the unspoken visual semiotic sign represented by her hair. ${ }^{2}$

Given that the Comendador has had sexual relations with many women, at least seven alleged to have consented through some form of enticement and at least two who did not (Jacinta and Laurencia), why would some critics read Laurencia as being the only woman powerful enough to withstand rape? If Laurencia had been a historical character, as are many of the others in the drama, and if these events had actually happened to her, she would most certainly have been raped. Not only is she bereft of help and male protection (a fact she makes patently clear when she reappears afterwards and berates the village men, most specifically her father, for their lack of action), but she is alone in the Comendador's palace with him and his men who could have easily overcome her, despite Nicole Mosher's provocative assertion that the Comendador may have actually been impotent and, therefore, unable to perform sexually. She does, however, fight back fiercely, as her body testifies. When the villagers appear before the Catholic Monarchs, Esteban summarizes the myriad complaints lodged against the Comendador, among them the rape of young village women: "Las haziendas nos robaba / y las donzellas forçaba, / siendo de piedad extraño." (3.2399-401). Frondoso personalizes the affront and insinuates the inevitability of Laurencia's rape, even while he attests to her virtue.

\footnotetext{
Tanto, que aquesta çagala

que el cielo me ha concedido, en que tan dichoso he sido
} 


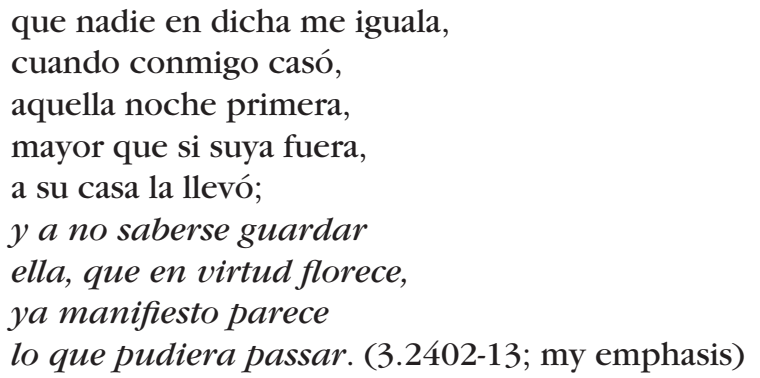

When Laurencia appears "desmelenada," her hair symbolizing emblematically her mistreatment and her rape, she delivers one of the most stirring and visceral oratories in early modern drama. She emphasizes the brutality of the physical assault she has endured and says, "y qué delitos atrozes, / por rendir mi castidad / a sus apetitos torpes! / Mis cabellos, ¿no lo dizen? / ¿No se ven aquí los golpes, / de la sangre, y las señales?" (2.1747-52)

Particularly compelling evidence of Laurencia's rape emerges in a brief exchange with Jacinta, the young woman whom the Comendador turned over to his soldiers to be gang-raped. When Laurencia speaks about Jacinta's gangrape, Jacinta commiserates with her in a gesture of solidarity by alluding to Laurencia's having suffered a similar indignation:

$\begin{array}{ll}\text { LAURENCIA. } & \begin{array}{l}\text { Jacinta, tu grande agravio, } \\ \text { que sea cabo; responde } \\ \text { de una escuadra de mujeres. }\end{array} \\ \text { JACINTA. } & \text { ¡No son los [agravios] tuyos } \\ & \text { menores! (3.1832-35) }\end{array}$

If Laurencia had only been beaten and not sexually dishonored, her "agravio" would have been less. One of the most troubling insinuations alleged by critics who argue that Laurencia was not raped is that her pivotal role in the drama would not have been possible if she had been raped. Laurencia's rape is given narrative priority over Jacinta's by its centralized ordering in the second act. However, the women themselves manifest an internal acknowledgment of the gravity of both rapes as violent acts that reach across social strata.

Jacinta appears infrequently in the drama, but her character and the manner in which she is staged warrant closer attention. She is only the second woman to reject the Comendador's advances and pays brutally for her attempt at selfpreservation, her gang-rape serving as a precursor to Laurencia's abduction and rape or possibly gang-rape (Elman 452). In the second act immediately following the scene in which Laurencia describes the Comendador's thwarted attack and Frondoso's defense (2.1137-84), Jacinta appears when she runs onto the stage fleeing the Comendador and his men as she pleads for help: "¡Dadme socorro, por Dios" (2.1185-275). Both of the other women present, 
Laurencia and Pascuala, also flee. Only Mengo remains to defend her, albeit unsuccessfully, as he is eventually dragged off stage to be beaten and she to be gang-raped. Jacinta does not appear again until the third act (3.1819-46) as part of the group of women who, at Laurencia's encouragement, form a squadron to seek vengeance. She appears one final time as part of the squadron of women seeking vengeance, especially from Flores (3.1888-919): “ $\mathrm{Ea}$, muera el traidor!” (3.1911); “iMueres, concertador de sus plazeres!” (3.1913). Her interventions represent her first as victim and later as avenger.

Linda Elman, in "None Dare Call it Rape: The Case of Laurencia," provides justification to account for Frondoso's possible "cover-up" (449) of Laurencia's rape when he appears before the Catholic Monarchs. By speaking of her enduring virtue, he seems to protect himself and Esteban from allegations of the Comendador's murder and to protect Laurencia's honor and reputation. Elman also suggests the unlikely possibility that Laurencia did not tell him she had been raped. While these are fascinating interpretations, there is textual evidence to suggest that Lope's concept of virtue-and that expressed by Fronsoso as he refers to Laurencia "que en virtud florece"-allows for a more complex and nuanced understanding, one that supersedes the limits of the physical body and resides in each person regardless of physical condition or condition of birth. Before Jacinta is abducted and brutally gang-raped by the Comendador's soldiers, suffering perhaps the most horrific injury of all the women in the drama, she tells him that honor-her father's and hers by association-is independent of socioeconomic class and, therefore, independent of the social body: "... porque tengo un padre honrado, / que si en alto nacimiento / no te iguala, en las costumbres / te vence" (2.1260-62).

The virtue to which Frondoso and Jacinta refer is not necessarily associated with virginity or chastity and does not necessarily limit itself to women. According to Thomas Wright in The Passions of the Minde in Generall (1604), "Virtue in the early modern culture was largely understood as selfgovernment, as a rational ruling of inordinate passions, or affections, deemed to be 'perturbations of the mind'" (Wright 7; Langis 2).

While the term virtue became increasingly more gendered by the early modern period-female virtue evoking sexual purity ${ }^{3}$-some humanists seemed to allow for a more fluid definition. For the Spanish humanist Juan Luis Vives, virtue might involve sexual virginity, particularly for women, and he dedicates at least two chapters to the topic in Education of a Christian Woman: A Sixteenth-Century Manual (De institutione feminae Christianae, 1523): "In a woman, chastity is the equivalent of all virtues. They are idle and slothful guardians who cannot guard the one thing committed to their care and enjoined upon them with many words and exhortations, especially when no one will take it from them against their will or touch it without their consent" (85). Moralists of the time adhered to the idea that if there were no consent, 
there would be no loss of virtue. St. Augustine suggested that even if there were no consent, shame could result from the fact that many might believe that there had been consent: ${ }^{4}$

But there can be committed on another's body not only acts involving pain, but also acts involving lust. And so whenever any act of the latter kind has been committed, although it does not destroy a purity which has been maintained by the utmost resolution, still it does engender a sense of shame, because it may be believed that an act, which perbaps could not bave taken place without some physical pleasure, was accompanied by a consent of the mind. (26; my emphasis)

Much to the discomfort of twenty-first century readers, Vives states that a woman cannot be raped against her will, and he provides anecdotal evidence to corroborate the murder of raped women by their fathers and brothers who believed that they had consented (84). However, Vives also suggests that virtue might involve the idea of an individual's self-control: "[W]hat greater practical wisdom is there than to know how and what the human passions are: how they are roused, how quelled?" (On Education 232). Despite this non-gendered understanding of virtue, medical thought at the time considered women to be humorally more prone to coldness than men and, therefore, "subject to all passions and perturbations" due to their "loose, soft and tender" flesh (Lemnius 274, 273; Langis 20-21). Fray Luis de León's La perfecta casada (1583), about the qualities of a virtuous woman (what he terms a mujer varonil), begins by equating the concept of virtue with virginity and sexual purity but seems to expand the concept to suggest a broader definition, one that "[q]uiere decir virtud de ánimo y fortaleza de corazón; industria y riquezas y poder y aventajamiento, $y$, finalmente, un ser perfecto y cabal en aquellas cosas a quien esta palabra se aplica; y todo esto atesora en sí la que es buena mujer, y no lo es si no lo atesora" (12).

Laurencia's physical abuse at the hands of the Comendador actually serves to strengthen her case for virtue. Many raped women suffer accusations of complicity and of whether or not they fought back, a criterion suggesting innocence, non-compliance. A brutal beating, in and of itself, does not compromise a person's honor and virtue, although in the case of women a sexual assault might.

Welles argues that Laurencia's virginity authorizes her to proceed with her marriage to Frondoso, thereby rendering a dramatic ending "appropriate to the paradigm of comedy and the mythos of romance" (89) and suggesting that marriage and the central role it plays in the drama would have been impossible 
if she had not been a virgin. Historian Allyson M. Poska, who has extensively studied Galicia in the early modern period, convincingly argues that premarital and extramarital sexual activity among women did not limit their marital choices and had little to do with perceptions of honor. In her study "Ellusive Virtue: Rethinking the Role of Female Chastity in Early Modern Spain," Poska notes that "The restrictive discourse on female sexuality and honor favored by Spanish elites and enthusiastically investigated by early modern historians had little resonance among the majority of the Spanish population" (136) and that "female chastity and honor ... [were] not central to the formulation of sexual mores among most Spaniards" (146). In another study, "An Ocean Apart. Reframing Gender in the Spanish Empire," she writes, "Women in central and southern Spain were more likely to conform to the constrained sexual expectations of the honor code than their counterparts in the north [Galicia], where illegitimacy rates were high, women married late, if at all, and inheritance patterns often favored women" (40). ${ }^{5}$

The rape victims Jacinta and Laurencia are women in need of male protection, without which, they are unable to defend themselves against the Comendador's sexual aggression, even though they do avenge themselves later. Wendy S. Hesford speaks compellingly of this dramatic structure, which she terms a "rape script," in "Reading Rape Stories: Material Rhetoric and the Trauma of Representation." Rape scripts refer to the act of rape as both material and representational reality and how these manifestations are shaped and structured by "historical, geopolitical, and cultural struggles, narratives, and fantasies" (193). These scripts "assign unequal status to women; women are construed as victims and men as every-threatening rapists" (Marcus 392). In keeping with strict binary gender roles, Pascuala's words to Jacinta obviate the responsibility of men to defend women against sexual assault:

LAURENCIA. Pues, Jacinta, Dios te libre, que cuando contigo es libre, conmigo será cruel.

PASCUALA. Jacinta, yo no soy hombre que te puedo defender. (2.1194-98)

Laurencia delivers an emotionally charged oratory to berate the village men, particularly her father, for their lack of action (3.1724-93), calling them "Liebres cobardes nacistes; / bárbaros sois, no españoles / ¡Gallinas! ¡Vuestras mujeres / sufrís que otros hombres gozen!" (3.1768-71).

When the Comendador's sexual appetite progresses from seduction to outright rape, Frondoso comes to Laurencia's defense (1.820-54), and Mengo comes to Jacinta's ("Yo sí lo tengo ser, / porque tengo el ser y el nombre" 2.1199-200). While Frondoso initially fends off the Comendador, he only postpones her abduction and rape until the Comendador appears at their 
wedding celebration with greater numbers to assist him in this effort. In fact, Gustavo Umpierre notes in "Songs in the Plays of Lope de Vega: A Study of Their Dramatic Function" that the lascivious song performed at the wedding foreshadows Laurencia's abduction (19). Mengo is unsuccessful in his attempt to defend Jacinta and is severely beaten for his efforts. These defensive efforts belie the apparent Amazonian strength the critics attribute to Laurencia when they insinuate that she alone of all of the other women fought back and was not raped when she admits an inability to defend her friend Jacinta and herself.

Studying the words of convicted rapists, Peter M. Kellet notes in "Acts of Power, Control, and Resistance: Narrative Accounts of Convicted Rapists" that many describe and justify rape "as a debt collection, a repayment, a reasonable revenge, or a re-balancing of justice" (148). They reframe the events in an effort to blame the victims and "to assert voice in the face of [their] own devalued otherness" (144). In the drama, Jacinta and Laurencia are violently raped (one gang-raped and the other brutally beaten and very possibly gang-raped as well) precisely because of their propensity to resist and to fight back, albeit unsuccessfully. The Comendador justifies their rapes because they could not be persuaded to submit by any other means and because he needs to demonstrate his power and authority over them.

Hesford also speaks of survivor narratives and how these may re-present and recreate the trauma experienced by rape victims (196). Laurencia has no need to re-present her trauma verbally by describing her torture and rape because her trauma is inscribed on her body: "Mis cabellos, ¿no lo dizen? / ¿No se ven aquí los golpes, / de la sangre, y las señales?" (3.1750-52). While her words may be interpreted as a hysterical response befitting a stereotypically traumatized woman (195), her words also serve as a call to action and do not serve to re-victimize her.

Hesford notes that "the strategic enactment of a culturally dominant rape script can potentially open up a gap within which that script can be contested and the act of rape or death resisted. ... [and that] strategies of appropriation can subvert dominant rape scripts even as they establish complicity with them" (197). This gap allows for the "fantasy of retribution" in which rape victims fantasize about the defeat and even the torture and killing of the rapists. This fantasy becomes dramatic reality in Fuenteovejuna. Although Jacinta and Laurencia are initially represented as powerless and weak when confronted with the power and strength of the Comendador and are raped, they rewrite, or rather subvert, the rape script to which they have been assigned when they become violent participants themselves in the actual revenge committed against the brutality of the Comendador. In fact, they re-vindicate their sexual trauma through a process of transgendering by which the women become as men, taking up weapons and assuming military identities. This transformation is particularly obvious in Laurencia as she comments, 


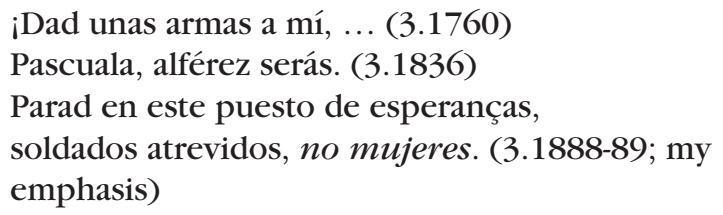

Elman describes the women's reenactment of their rapes through the visual image of phallic swords (452) and "phallocentric rhetoric" (Allatson 267). For one explicit example, Laurencia avenges her rape by the Comendador by using the sword to penetrate his palace in a similar manner in which he used his penis to penetrate her: "Pascuala, yo entro dentro; que la espada / no ha de estar tan sujeta ni envainada" (3.1904-05). Elman also provocatively interprets the sexualized nature of the Comendador's crossbow "that imitates the female's spread legs while the arrow, symbolic of the phallus, penetrates up the middle" (450).

When the women participate in the attempted murder of Flores, one of the Comendador's henchmen, it is Pascuala (not Jacinta) who proposes to avenge Mengo's beating — "Vengaré tus açotes" (3.1911)—thereby assuming a traditionally male role. The henchmen try to save their own lives by begging for mercy as they attempt to re-inscribe the women in traditional female gender roles. Flores expresses shock that the women, normally victims and not perpetrators, take part in the violence ("¿Entre mujeres?" 3.1914), and, in a tactic designed to save his life, he begs for mercy (“iPiedad, señoras!” 3.1915), a similar mercy that was denied to Jacinta ("iPiedad, señor!" 2.1273) when the Comendador handed her over to his soldiers to be gang-raped. Those who refute Laurencia's rape adhere unwittingly to a culturally dominant rape script, which requires that she, as a rape victim, would not behave in the violent way that she does and would not be recognized as possessing virtue, particularly by her fiancé or husband.

In Cervantes's Don Quijote de la Mancha, Sancho's wife Teresa writes a letter in which she describes life in the village, life often fraught with danger as village girls risk being carried off and raped (and gang-raped) by marauding soldiers:

Hogaño no hay aceitunas, ni se halla una gota de
vinagre en todo este pueblo. Por aquí pasó una
compañía de soldados: lleváronse de camino tres
mozas deste pueblo; no te quiero decir quién son:
quizá volverán y no faltará quien las tome por
mujeres, con sus tachas buenas o malas. (II, 52,
1157; my emphasis)

Teresa, however, observes that even raped women might marry and find happiness, suggesting that the technicalities of lost virginity or chastity may not actually be impediments to personal virtue and marital satisfaction. 
Although Laurencia and Frondoso may not yet have sexually consummated their marriage by the time they appear before the Catholic Monarchs, they confess their love and affection for one another publically after having survived a horrifically traumatic experience. Both appear to anticipate marital happiness and fulfillment as Laurencia refers to Frondoso as her beloved husband- "Mi esposo adoro" (2.2169) and "¡Esposo amado!” (3.2175)—and he describes her as "aquesta çagala / que el cielo me ha concedido, / en que tan dichoso he sido / que nadie en dicha me iguala” (3.2402-05).

Lope's Fuenteovejuna addresses that gap identified by Hesford between the rape script (the proscriptive rape scenes that inevitably play out again and again) and its strategic enactment, that gap "within which that script can be contested and the act of rape or death resisted. ... strategies of appropriation can subvert dominant rape scripts even as they establish complicity with them" (Hesford 197). This gap is articulated through the raped bodies of Laurencia and Jacinta. On the one hand, specifically Laurencia and Jacinta, along with the other raped female characters, comply with culturally dominant rape scripts by asserting their need for male protection and revenge and by succumbing to rape (despite some critics' opinions to the contrary). For Kathryn Gravdal, whose study of the medieval French pastourelle, "Sexual Violence in the Medieval Pastourelle," reveals points of intersection with this comedia, rape is represented "as the inevitable encounter between the representatives of two different social classes" (365), that social class represented by the Comendador and that social class represented by the villagers. On the other, they also subvert these same rape scripts and open a gap by avenging themselves and inciting the men to do likewise. While Laurencia appears as "avenging amazon" (Allatson 266) and employs "phallocentric rhetoric" (267) to shame the village men into behaving in a manner commensurate with their assigned gender roles, she and the other women subvert their own gender roles. Through a process of transgendering, these women actively transform their socially designated gender roles and become de facto men, even going so far as to simulate the rape of the Comendador and his henchmen with swords that serve as prosthetic phalluses. While comedias often function as a method by which to enact "social control and ideological dissemination" (Howard 4), Fuenteovejuna subverts its own rape script, thereby resulting in "disturbances to the neat picture of male dominance and complete female subjugation" (Allaton 261). According to Judith Butler:

Gender is not passively scripted on the body [. . . nor . . .] determined by nature, language, the symbolic, or the overwhelming history of patriarchy. Gender is what is put on, invariably under constraint, daily and incessantly, with anxiety and pleasure [...]. (282) 
For Laurencia and Jacinta, gender identification as raped women is not passive or natural but instead violently scripted on their bodies, scripted in such a way that the audience-both the audience composed of village members and the audience viewing the comedia-reads and recognizes immediately the violence to which they have been subjected. Perhaps more provocatively, by articulating the gap between the rape script and its strategic enactment, these literary women create a gap or a space between the concept and the act. They do this by demonstrating the provocative idea that the concept of virtue is not determined by or limited to actual female virginity and may exist independently from the physical body. Characters ensure the public recognition of this virtue in the presence of the social body, just as Frondoso does before the Catholic Monarchs and Jacinta does defiantly before the Comendador. In such a stratified social milieu, one which places these women at high risk for rape and sexual violence because of their gender (as women) and because of their socially disadvantageous position (as villagers), a strategy must exist to cope and supersede the inevitable loss of physical virtue by supplanting it with moral virtue. Elman notes, "Ultimately she [Laurencia] represents restored order ('en virtud florece') during the denouement, consistent with the typical resolution of the Spanish comedias" (453). And yet the restoration of this order is enacted through a subversion of the very order it purports to reflect: women behave as shamefully as men, and the villagers violate social boundaries to avenge themselves of the Comendador. The requisite restoration of order in Fuenteovejuna is attained by a radical re-visioning of the rape script and by an understanding of a more fluid concept of virtue.

\section{Notes}

1. As early as $730-44$, the Lex Baiuvariorum specified that a rape victim, to be deemed credible, must reveal her fluttering hair ("flatterndem haar") and torn clothing ("zerrißnem gebend") to signify that she had been raped. In addition, Henry de Bracton's thirteenth-century law code also demanded that the rape victim show her torn clothing (Wolfthal 43).

2. In the Rakatá theatrical company production of 2009 in Madrid, the character of Laurencia also appears with torn and bloody clothing.

3. Unhae Park Langis suggests that virtue was understood during the early modern period "more as a prudent deployment of emotion and action than a rational suppression of the passions" (3). For a detailed denotative understanding of how the meaning of virtue began to shift according to gender, see 20 .

4. Pregnancy resulting from a rape could exonerate a rapist in seventeenth-century Somerset, England, according to G. R. Quaife. Michael Dalton concurs and notes that if the woman at the time of the supposed rape, do conceive with child, by the ravisher, this is no rape, for a woman cannot conceive with child except she do consent" (172; my emphasis). This sentiment echoes that of some contemporary GOP politicians, most notoriously Todd Akin, the Republican nominee for the Missouri State Senate, who noted, "If it's a legitimate rape, the female body has ways to try to shut that whole thing down." 


\section{Works Cited}

Allatson, Paul. "Confounding Convention: 'Women' in Three Golden Age Plays." Bulletin of the Comediantes 48.2 (1996): 261-273. Project Muse. Web. 7 Jan. 2015.

Augustine, Saint. City of God. Ed. David Knowles. Trans. Henry Bettenson. Harmondsworth: Penguin, 1972.

Barahona, Renato. Sex Crimes, Honour, and the Law in Early Modern Spain. Vizcaya, 1528-1735. Toronto: U of Toronto P, 2003.

Butler, Judith. "Performative Acts and Gender Constitution: An Essay in Phenomenology and Feminist Theory." Performing Feminisms: Feminist Critical Theory and Theatre. Ed. Sue-Ellen Case. Baltimore: Johns Hopkins UP, 1990.

Casalduero, Joaquín. Estudios sobre el teatro español. Madrid: Gredos, 1981.

Cervantes Saavedra, Miguel de. Don Quijote de la Mancha. Edition from the Instituto Cervantes (1605-2005). Ed. Francisco Rico. Barcelona: Galaxia Gutenberg, 2005.

—. "La fuerza de la sangre." Novelas ejemplares II. Ed. Juan Bautista Avalle-Arce. Madrid: Castalia, 1982. 145-71.

Córdoba de la Llave, Ricardo. "A una mesa y una cama. Barraganía y amancebamiento a fines de la edad media." Saber y vivir: Mujeres, antigüedad y medievo. Ed. María Isabel Calero Secall and Rosa Francia Somalo. Málaga: Universidad de Málaga, 1996. 129-53.

Dalton, Michael. The Countrey Justice. Norwood, NJ: Walter J. Johnson, 1975.

Dillard, Heath. Daughters of the Reconquest. Cambridge: Cambridge UP, 1984.

Dixon, Victor. "'Su Majestad habla, en fin, como quien tanto ha acertado.' La conclusión ejemplar de Fuente Ovejuna." El Criticón 42 (1988): 155-68.

Dyer, Abigail. "Seduction by Promise of Marriage: Law, Sex, \& Culture in $17^{\text {th }}$-Century Spain." Sixteenth Century Journal 34.2 (2003): 439-55.

Elman, Linda L. "None Dare Call it Rape: The Case of Laurencia." Romance Languages Annual 8 (1997): 449-54.

Gravdal, Kathryn. "Sexual Violence in the Medieval Pastourelle." Romanic Review 76 (1985): 361-73.

Halper, Katie. "The 7 Most Outrageous GOP Explanations For Why Rape Victims Can't Get Pregnant." Policy.Mic, 14 June 2013. Web. 21 Sept. $2014<$ http://mic.com/articles/48691/the-7most-outrageous-gop-explanations-for-why-rape-victims-can-t-get-pregnant $>$.

Hesford, Wendy S. "Reading Rape Stories: Material Rhetoric and the Trauma of Representation." College English 62.2 (November 1999): 192-221. JSTOR. Web. 23 Mar. 2014.

Howard, Jean. The Stage and Social Struggle in Early Modern England. London: Routledge, 1994.

Kellet, Peter M. "Acts of Power, Control, and Resistance: Narrative Accounts of Convicted Rapists." Hate Speech. Ed. Rita Kirk Whillot and David Slayden. Thousand Oaks: Sage, 1995. 142-62.

Langis, Unhae Park. Passion, Prudence, and Virtue in Shakespearean Drama. London and New York: Continuum International Publishing Group, 2011.

Lemnius, Levinus. De miraculis occultis naturea. Anon. trans. As The Secret Miracles of Nature. London: Humphrey Mosley, 1658.

León, Fray Luis de. La perfecta casada (1583). Mexico City: Porrúa, 1999.

Marcus, Sharon. "Fighting Bodies, Fight Words: A Theory and Politics of Rape Prevention." Feminists Theorize the Political. Ed. Judith Butler and Joan W. Scott. New York: Routledge, 1992. 385-403.

Mosher, Nicole. "La impotencia de Fernán Gómez de Guzmán ante la virtud de Laurencia." University of South Florida Language Quarterly 23.1-2 (1984): 15-16, 21.

Poska, Allyson M. "Ellusive Virtue: Rethinking the Role of Female Chastity in Early Modern Spain." Journal of Early Modern History 8.1 (2004): 125-46.

- "An Ocean Apart: Reframing Gender in the Spanish Empire." Women of the Iberian Atlantic. Ed. Sarah Owens and Jane E. Mangan. Baton Rouge: Louisiana State UP, 2012. 37-56.

- Women and Authority in Early Modern Spain: The Peasants of Galicia. Oxford: Oxford UP, 2006.

Quaife, G. R. Wanton Wenches and Wayward Wives: Peasants and Illicit Sex in Early Seventeenth Century England. New Brunswick: Rutgers UP, 1979. 
Testón Nuñez, Isabel. Amor, sexo y matrimonio en Extremadura. Badajoz: Universitas Editorial, 1985.

Thompson, I. A. A. War and Government in Habsburg Spain 1560-1620. London: Athlone, U of London, 1976.

Umpierre, Gustavo. Songs in the Plays of Lope de Vega: A Study of Their Dramatic Function. London: Tamesis, 1975.

Vega, Lope de. Fuente Ovejuna. Ed. Juan María Marín. Madrid: Cátedra 2009.

Vives, Juan Luis. Education of a Christian Woman: A Sixteenth-Century Manual. (De institutione feminae Christianae, 1523). Trans. Charles Fantazzi. Chicago: U of Chicago P, 2000. Web. 6 Mar. 2014. <http://site.ebrary.com/lib/morrismn/docDetail.action>.

- On Education: a Translation of the De tradendis disciplines. Trans. Foster Watson. Cambridge: Cambridge UP, 1913.

Welles, Marcia L. Persephone's Girdle: Narratives of Rape in Seventeenth-Century Spanish Literature. Nashville: Vanderbilt UP, 2000.

Wolfthal, Diane. Images of Rape: The "Heroic" Tradition and Its Alternatives. Cambridge: Cambridge UP, 1999.

Wright, Tomas. The Passions of the Minde in Generall (1604). Ed. Thomas O. Sloane. Urbana: U of Illinois P, 1971. 